\title{
Budaya Berbusana Batik pada Generasi Muda
}

\author{
Fony Sanjaya $^{(1)}$, Listyo Yuwanto ${ }^{(1)}$ \\ ${ }^{(1)}$ Fakultas Psikologi, Universitas Surabaya, Surabaya, Indonesia
}

\begin{abstract}
Batik is the world's cultural heritage that is recognized as originating from Indonesia. Nowadays batik becomes a lifestyle for the young generation. Batik lifestyle behavior can be explained through the theory of planned behavior. The aim of this study was to investigate the intentions of using batik among members of the younger generation based on their attitudes towards batik, subjective norms about batik, and control of batik lifestyle behavior. The study was conducted by giving an opened questionnaire to 30 respondents consisting of 7 men and 23 women in the East Java area. This step is accompanied by a semi-structured interview that was conducted with two respondents. The results of the questionnaire show that there are several factors that encourage the younger generation to dress in batik, including aesthetics, prestige, fashionable, national identity, and flexibility. The aesthetic value of batik is the main intention to dress batik among members of the younger generation, which is driven by their attitudes towards batik and control of batik lifestyle behavior. The current research also shows that family is the driving factor (subjective norm) for the young generation to dress in batik.
\end{abstract}

Keywords: batik, the young generation, batik lifestyle, the theory of planned behavior

Batik merupakan warisan budaya dunia yang diakui berasal dari bangsa Indonesia. Dewasa ini batik menjadi gaya hidup berbusana generasi muda. Perilaku berbusana batik dapat dijelaskan melalui theory of planned behavior (teori perilaku terencana). Penelitian ini bertujuan untuk mengetahui intensi berbusana batik pada generasi muda yang didasari oleh sikap terhadap batik, norma subyektif tentang batik, dan kontrol terhadap perilaku berbusana batik. Penelitian dilakukan dengan memberikan angket terbuka kepada 30 orang responden yang terdiri dari 7 orang laki-laki dan 23 orang perempuan di area Jawa Timur. Setelah itu dilakukan wawancara semi terstruktur kepada 2 orang dari responden tersebut. Hasil angket menunjukkan faktor-faktor yang mendorong generasi muda berbusana batik yaitu nilai estetika, prestise, fashionable, identitas bangsa, dan fleksibilitas. Nilai estetika pada batik merupakan intensi utama menggunakan pakaian batik pada generasi muda yang diprediksi oleh sikap terhadap batik dan kontrol terhadap perilaku berbusana batik. Penelitian ini juga menemukan bahwa keluarga adalah faktor pendorong (norma subyektif) generasi muda menggunakan batik.

Kata kunci: batik, generasi muda, berbusana batik, theory of planned behavior

MEDIAPSI, 2019, Vol. 5(2), 88-96, DOI: https://doi.org/10.21776/ub.mps.2019.005.02.3

Received: 2019-06-24. Revised: 2019-09-11. Accepted: 2019-11-29. Published online: 2019-12-05

Handling Editor:Intan Rahmawati, Universitas Brawijaya, Malang, Indonesia

*Corresponding author: Fony Sanjaya, Fakultas Psikologi, Universitas Surabaya, Surabaya, Indonesia. E-mail: leafony@gmail.com

\section{(cC) (i) 8}

This work is licensed under a Creative Commons Attribution-NonCommercial 4.0 International License.

How to cite this article in accordance with the American Psychological Association (APA) ${ }^{\text {th }}$ guidelines:

Sanjaya. F., \& Yuwanto, L. (2019). Budaya berbusana batik pada generasi muda. MEDIAPSI, 5(2), 88-96.

DOI: https://doi.org/10.21776/ub.mps.2019.005.02.3

\section{Pendahuluan}

Batik merupakan warisan budaya dunia

yang diakui berasal dari bangsa Indonesia. Batik ditetapkan sebagai Indonesian Cultural Heritage (warisan budaya bukan benda) oleh UNESCO (United Nations Educational,
Scientific and Cultural Organization) pada tanggal 2 Oktober 2009 (Galih, 2017). Sejak saat itu setiap tanggal 2 Oktober diperingati sebagai Hari Batik Nasional. Batik menjadi identitas budaya Bangsa Indonesia di era globalisasi. Batik memiliki kekhasan dan 
keunikan yang membedakan bangsa Indonesia dengan bangsa lain. Batik berasal dari Bahasa Jawa "amba" dan "titik" yang berarti menulis titik. Batik lekat dengan kebudayaan Jawa meskipun batik juga bersentuhan dengan budaya lain (Felaza, 2015; Yunus \& Tulasi, 2012). Batik Jawa memiliki berbagai macam motif yang kental akan filosofi hidup ( $\mathrm{Li}, \mathrm{Hu}$, \& Yao, 2009).

Batik Jawa dengan ragam hias dan motifnya memiliki fungsi masing-masing mulai dari fungsi untuk menggendong bayi, untuk alas, selimut, khusus dipakai raja, khusus dipakai pengantin sampai kain penutup jenazah (Iskandar \& Kustiyah, 2017). Pemakaian batik tidak bisa secara sembarangan karena disesuaikan dengan filosofi motif batik yang terkandung di dalamnya (Stephenson, 1993).

Saat ini pemakaian batik tidak lagi hanya terlihat pada acara-acara seremonial, namun juga pada acara informal sampai acara santai. Batik dipakai oleh semua lapisan masyarakat, baik tua maupun muda, tingkat perekonomian menengah ke atas maupun menengah ke bawah (Gray, 2010). Bahkan berpakaian batik setiap hari Kamis dan Jumat untuk seluruh Pegawai Negeri Sipil (PNS) maupun Pegawai Tidak Tetap (PTT) menjadi salah satu instruksi Gubernur DKI Jakarta No. 27 tahun 2012 tentang penggunaan pakaian dinas harian batik yang mulai berlaku tanggal 5 April 2012 ("Kamis dan Jumat wajib pakai Batik," 2012). Batik berada pada puncak popularitasnya ketika batik mendapat tempat di hati para milenial. Batik telah menjadi gaya hidup berbusana generasi muda (Simatupang, Afrillia, Maharrani, \& Pujiono, 2016).

Menurut pandangan psikologi, perilaku berbusana batik dapat dijelaskan melalui theory of planned behavior (teori perilaku terencana). Teori ini menjelaskan bahwa perilaku seseorang muncul karena adanya niat (intensi). Intensi merupakan kemauan untuk melakukan perilaku, sehingga kekuatan intensi dilihat dari besarnya kemauan individu untuk melakukan perilaku tersebut (Ajzen, 2005). Niat untuk melakukan perilaku dapat diukur menggunakan tiga prediktor utama yaitu sikap terhadap perilaku (attitude toward the behavior), norma subyektif (subjective norm), dan persepsi terhadap kontrol perilaku (perceived behavioral control).

Perilaku berbusana batik tidak lepas dari perilaku pembelian. Beberapa penelitian telah dilakukan terkait dengan perilaku membeli batik. Risnamasari, Mujiasih, dan Putra (2013) melalui penelitiannya menjelaskan bahwa terdapat hubungan positif antara persepsi terhadap kualitas produk dengan intensi membeli batik. Kusumodewi dan Sudarwanto (2016) menuliskan gaya hidup, kualitas produk, dan harga berpengaruh signifikan terhadap keputusan pembelian secara simultan dan harga merupakan variabel yang paling dominan. Azhar dan Siswanto (2018) melakukan survey kecenderungan masyarakat khususnya remaja terhadap batik dan hasilnya adalah sebagian besar responden lebih sering berbusana batik untuk acara formal, sedangkan pemakai batik sebagai pakaian kasual masih minim.

Fenomena berbusana batik pada generasi muda belum pernah diteliti. Peneliti melakukan pencarian literatur menggunakan pangkalan data google dan google scholar menggunakan kata kunci batik, batik sebagai gaya hidup, batik sebagai gaya hidup generasi muda, persepsi terhadap batik. Generasi muda yang identik dengan sesuatu yang berbau modern sejatinya berbusana berkiblat pada budaya unggul (fashion busana Eropa atau Amerika). Meskipun demikian, banyak didapati generasi muda berbusana batik sebagai pakaian sehari-hari.

Penelitian ini bertujuan untuk mengetahui intensi berbusana batik pada generasi muda yang didasari oleh sikap terhadap batik, norma subyektif tentang batik, dan kontrol terhadap perilaku berbusana batik. Penelitian ini diharapkan dapat mengungkapkans realita sosial dari generasi muda pengguna batik dilihat dari aspek psikologisnya, sehingga dengan demikian penelitian ini dapat dijadikan acuan literatur 
mengenai batik untuk penelitian-penelitian selanjutnya.

\section{Metode}

\section{Desain penelitian}

Penelitian ini didesain sebagai penelitian kualitatif dengan pendekatan fenomenologi (Creswell, Hanson, Clark Plano, \& Morales, 2007). .Dengan pendekatan ini, peneliti menggali, melalui sejumlah pertanyaan, bagaimana sikap, intensi, dan pengalaman responden terkait dengan gaya hidup berbusana batik.

\section{Responden penelitian}

Responden yang berpartisipasi dalam penelitian ini adalah generasi muda Jawa Timur kelahiran tahun 1980 sampai 2000 yang memiliki kebiasaan berbusana batik pada kesehariannya (pemakaian batik di luar ketentuan berseragam di kantor ataupun instansi tertentu). Responden yang mengisi kuesioner dengan pertanyaan terbuka berjumlah 30 yang terdiri dari 7 laki-laki dan 23 perempuan. Responden diwawancarai secara semi terstruktur, yang terdiri dari 2 orang yang diambil dari responden yang mengisi kuesioner dengan pertanyaan terbuka. Responden pertama (Agus) adalah seorang laki-laki berusia 23 tahun dengan etnis Jawa, latar belakang Budaya Jawa, dan berdomisili di Surabaya. Responden kedua (Siska) adalah seorang wanita berusia 39 tahun dengan etnis Tionghoa, memiliki latar belakang Budaya Jawa, dan berdomisili di Banyuwangi.

\section{Instrumen penelitian}

Metode pengumpulan data dalam penelitian ini menggunakan kuesioner dengan pertanyaan terbuka yang disusun menggunakan acuan theory of planned behavior (Ajzen, 2005). Kuesioner dengan pertanyaan terbuka memberikan kebebasan partisipan untuk menjawab berdasarkan persepsi dan pengalamannya. Pertanyaan terdiri dari: "Mengapa Anda suka berbusana batik? (attitude toward the behavior)" "Bagaimana pandangan Anda mengenai batik? (attitude toward the behavior)" "Siapakah yang mempengaruhi MEDIAPSI | 2019, Vol. 5, No. 2, 88-96
Anda sehingga Anda suka berbusana batik? (subjective norms)" "Apakah yang jadi pertimbangan Anda saat berbusana batik? (perceived behavioral control)", dan "Apakah yang menjadi pendorong Anda untuk berbusana batik? (intention)".

Pengumpulan data juga dilakukan menggunakan semi structured interview (Kallio, Pietilä, Johnson, \& Kangasniemi, 2016). Peneliti melakukan wawancara kepada 2 orang responden. Kedua responden dipilih dengan menggunakan metode purposive sampling (Teddlie \& Yu, 2007). Keduanya diketahui oleh peneliti sebagai pengguna batik dalam berbusana sehari-hari (bukan karena seragam). Panduan wawancara disusun berdasarkan jawaban responden pada pertanyaan terbuka. Pertanyaan berupa probing (Frey \& Fontana, 1991) dengan tujuan mengetahui lebih dalam alasan dan keyakinan reponden mengenai batik sehingga membentuk perilaku pemakaian.

\section{Hasil}

Analisis data dilakukan secara deskriptif. Data diambil dari data primer yang diperoleh langsung dari sumber utama. Data deskriptif dianalisis dengan mengeksplorasi respon dari kuesioner dengan pertanyaan terbuka. Tahapannya adalah sebagai berikut: (1) menyiapkan data, (2) mengelompokkan jawaban berdasarkan kata kunci, (3) membuat kategori kecil berdasarkan kesamaan tema, (4) menganalisis menggunakan cross-tabulation (tabulasi silang) setiap aspek (Robinson, 2014). Proses kategorisasi dilakukan dengan cara menggabungkan jawaban responden yang memiliki kesamaan (Smit, 2002). Dalam proses kategorisasi, dimulai dari kategori besar kemudian disempurnakan menjadi kategori lebih kecil. Hasil menunjukkan bahwa kategori besar terdiri dari kategori spesifik, sementara kategori yang lebih kecil terdiri dari kategori spesifik yang telah digeneralisasi. Tabulasi silang menunjukkan respons dari sekelompok sampel. Analisis dilakukan dengan membagi variabel penelitian ke dalam kategori 
berdasarkan tabel frekuensi. Data kualitatif yang berasal dari wawancara semi terstruktur dianalisis menggunakan pengujian asumsi atau permasalahan yang ada terhadap data, mencari alternatif penjelasan bagi data, kemudian menulis hasil penelitian (Turner III, 2010).

Berikut ini adalah hasil analisis kuesioner terbuka dan wawancara dengan responden.

Tabel 1. Alasan Responden Suka Berbusana Batik

\begin{tabular}{lcc}
\hline \multicolumn{1}{c}{ Kategori } & Frekuensi & $\begin{array}{c}\text { Persentase } \\
(\%)\end{array}$ \\
\hline $\begin{array}{l}\text { Estetika (motif, corak, nilai seni) } \\
\text { Identitas bangsa (khas Indonesia) }\end{array}$ & 9 & 30 \\
$\begin{array}{l}\text { Fleksibilitas (cocok dengan semua } \\
\text { acara) }\end{array}$ & 7 & 23.3 \\
$\begin{array}{l}\text { Prestise (elegan, berwibawa, } \\
\text { anggun) }\end{array}$ & 4 & 23.3 \\
$\begin{array}{l}\text { Fashionable (keren, modis) } \\
\text { Total }\end{array}$ & 3 & 13.3 \\
\hline
\end{tabular}

Tabel 2. Sikap Responden Mengenai Batik

\begin{tabular}{lcc}
\hline \multicolumn{1}{c}{ Kategori } & Frekuensi & $\begin{array}{c}\text { Persentase } \\
(\%)\end{array}$ \\
\hline Identitas bangsa (warisan budaya) & 16 & 53.3 \\
Estetika (indah, seni) & 5 & 16.7 \\
Fleksibilitas (cocok untuk semua & 4 & 13.3 \\
acara) & & \\
Prestise (berkelas) & 3 & 10 \\
Fashionable (keren, modis) & 2 & 6.7 \\
Total & 30 & 100 \\
\hline
\end{tabular}

Tabel 3. Hal yang Mempengaruhi Responden Sehingga Suka Berbusana Batik

\begin{tabular}{lcc}
\hline \multicolumn{1}{c}{ Kategori } & Frekuensi & $\begin{array}{c}\text { Persentase } \\
(\%)\end{array}$ \\
\hline $\begin{array}{l}\text { Kerabat (orang tua, saudara, kakek, } \\
\text { leluhur) }\end{array}$ & 13 & 43.3 \\
Diri sendiri & 7 & 23.3 \\
Tidak ada & 4 & 13.3 \\
Orang sekitar (teman, komunitas & 5 & 16.7 \\
gereja, selebgram) & & \\
Media (TV) & 1 & 3.3 \\
Total & 30 & 100 \\
\hline
\end{tabular}

Tabel 4. Pertimbangan Responden Saat Berbusana Batik

\begin{tabular}{|c|c|c|}
\hline Kategori & Frekuensi & $\begin{array}{c}\text { Persentase } \\
(\%)\end{array}$ \\
\hline $\begin{array}{l}\text { Estetika (motif, model, } \\
\text { bahan) }\end{array}$ & 12 & 40 \\
\hline $\begin{array}{l}\text { Fleksibilitas (cocok dengan } \\
\text { semua acara) }\end{array}$ & 10 & 33.3 \\
\hline Prestise (elegan) & 3 & 10 \\
\hline $\begin{array}{l}\text { Fashionable (modis, } \\
\text { keren) }\end{array}$ & 3 & 10 \\
\hline Identitas bangsa & 2 & 6.7 \\
\hline Total & 30 & 100 \\
\hline
\end{tabular}

Tabel 5. Intensi Responden Berbusana Batik

\begin{tabular}{lcc}
\hline \multicolumn{1}{c}{ Kategori } & Frekuensi & $\begin{array}{c}\text { Persentase } \\
(\%)\end{array}$ \\
\hline $\begin{array}{l}\text { Estetika (motif, model, } \\
\text { bahan) }\end{array}$ & 9 & 30 \\
$\begin{array}{l}\text { Prestise (elegan, lebih } \\
\text { berwibawa) }\end{array}$ & 2 & 16.7 \\
$\begin{array}{l}\text { Fashionable (keren) } \\
\begin{array}{l}\text { Identitas bangsa } \\
\text { Fleksibilitas (cocok }\end{array}\end{array}$ & 4 & 13.3 \\
$\begin{array}{l}\text { dengan semua acara) } \\
\text { Total }\end{array}$ & 8 & 26.7 \\
\hline
\end{tabular}

\section{Diskusi}

Berdasarkan kategorisasi data pada bagian hasil dapat disimpulkan bahwa perilaku berbusana batik generasi muda disebabkan oleh alasan estetika (motif, corak, nilai seni), prestise (anggun, berwibawa, berkelas), fashionable (keren, modis), identitas bangsa (warisan budaya), dan flexibility (cocok untuk semua acara). Kamus Besar Bahasa Indonesia (KBBI) menjelaskan pengertian dari estetika melalui dua sudut pandang. Poin pertama menyatakan bahwa estetika merupakan salah satu ilmu dari cabang filsafat yang membahas tentang seni dan keindahan serta bagaimana tanggapan manusia terhadap seni dan keindahan. Poin kedua menyatakan bahwa estetika adalah salah satu sarana kepekaan terhadap seni dan keindahan ("Arti kata estetika," n.d.). Berdasarkan definisi di atas maka jawaban responden yang berkaitan dengan motif, corak, keindahan, nilai seni pada batik termasuk ke dalam estetika.

Status sosial sering pula disebut sebagai kedudukan atau posisi, peringkat seorang individu dalam kelompok masyarakatnya. Status sosial berkaitan dengan prestise (Cheng \& Tracy, 2014). Prestise adalah status sosial, kehormatan, dan kedudukan individu dalam kehidupannya (Maner \& Case, 2016). Responden merasa elegan dan anggun, membuat penampilan individu tampak berwibawa saat berbusana batik, sehingga hal tersebut mengarah kepada prestise.

Fashionable memiliki suatu makna 'conforming to the fashion or established mode' (Cholachatpinyo, Fletcher, Padgett, \& Crocker, 
2002), yang di dalam bahasa Indonesia diartikan modis. Beberapa responden menjawab bahwa batik itu fashionable, modis, keren, up to date. Hal tersebut terkait dengan konformitas yang dilakukan responden untuk menjadi sebuah bagian komunitas. Demikian halnya dengan batik sebagai identitas bangsa yang juga merupakan bentuk dari konformitas dari masyarakat Indonesia. Dengan berbusana batik maka responden merasa menjadi bagian dari negara Indonesia.

Batik dianggap sesuai dipakai di berbagai acara, baik formal maupun informal (Iriani, 2013). Batik membuat pemakainya merasa aman dari penilaian orang lain. Batik bisa dipakai untuk style casual maupun resmi, bahkan batik juga bisa dipakai saat santai. Dengan demikian batik dapat dikatakan memiliki fleksibilitas. Fleksibilitas batik membuat pemakainya merasa luwes saat berbusana batik.

Tabel 1 menunjukkan alasan utama responden suka berbusana batik karena motif, corak, atau nilai seni batik. Contoh pernyataan yang menunjukkan responden menyukai batik karena nilai estetikanya seperti:

"Suka dengan semua motif batik"

"Punya nilai seni"

\section{"Suka coraknya"}

Iskandar dan Kustiyah (2017) menjelaskan bahwa popularitas batik mulai meningkat pada akhir abad ke-18 atau awal abad ke-19. Era industrialisasi ditandai dengan munculnya batik cap kemudian batik printing. Pengaruh globalisasi menggeser nilai seni batik dari seni yang penuh filosofis, religious, dan simbolik berubah menjadi seni yang bersifat material semata (Djulius, 2017). Karya seni yang seperti ini tercipta karena kebutuhan praktis dan ekonomis.

Penjelasan tersebut didukung oleh hasil wawancara dengan Siska yang mengatakan bahwa alasannya menyukai batik karena motif batik memiliki nilai seni yang tinggi. Siska menyukai cara pembuatan batik yang handmade. Semakin tinggi tingkat kerumitannya maka harganya semakin mahal. Siska berbusana batik tulis dengan bahan yang bagus pada acara penting. Dengan demikian Siska akan merasa lebih percaya diri dan dinilai dengan status sosial lebih tinggi.

Tabel 2 menunjukkan tentang sikap (pandangan) utama responden suka terhadap batik adalah batik merupakan warisan budaya dan identitas bangsa Indonesia. Contoh pernyataan yang menunjukkan sikap utama responden terhadap batik seperti:

\section{"Batik adalah identitas kita sebagai orang Indonesia"}

"Warisan budaya yang luar biasa cantik, dan tidak lekang oleh waktu. Masih masuk untuk masa sekarang"

"Budaya Indonesia yang harus diperkenalkan ke seluruh dunia"

$$
\text { Iskandar dan Kustiyah }
$$

menuliskan bahwa masyarakat Indonesia memiliki kesadaran kolektif untuk mengenakan baju batik karena batik merupakan warisan leluhur bangsa Indonesia dan identitas bangsa. Batik yang awalnya hanya dipakai di lingkungan keraton saja, saat ini mulai dipakai di luar keraton bersamaan dengan kebutuhan dan perkembangan zaman dari kebutuhan individual menjadi kebutuhan industrial.

Marwati (2011) menambahkan bahwa pakaian tidak lagi hanya berfungsi sebagai pelindung tubuh dan menutupi bagian-bagian tubuh tertentu untuk memenuhi fungsi kesopanan, akan tetapi pakaian sudah menjadi perlengkapan atau habitus untuk menunjukkan identitas manusia atau dalam lingkup yang lebih luas, pakaian bisa menjadi identitas nasional dan kultural. Mengenakan baju batik bisa menjadi sebuah bentuk tanda resistensi atas "budaya unggul" (high culture). Budaya unggul dalam pakaian contohnya adalah jas dengan dasi ataupun gaun-gaun dari Eropa. Mengenakan batik merupakan suatu simbol perlawanan atas pakaian resmi berupa jas, dasi, atau gaun-gaun Eropa dari budaya asing. 
Dengan berbusana batik, maka identitas Indonesia ditunjukkan, dan menjadi unsur pembeda dengan bangsa lain (Moersid, 2013).

Tabel 3 menunjukkan bahwa pihak yang mempengaruhi responden sehingga suka berbusana batik adalah kerabat. Kerabat yang dimaksud adalah keluarga yaitu orang tua terutama ibu dan kakek. Shokiyah (2012) menjelaskan bahwa melalui orang tua anak belajar mengenal nilai, peran sosial, norma, adat istiadat yang ditanamkan orang tuanya. Orang tua merupakan pengatur norma-norma masyarakat kepada anaknya, keluarga merupakan jembatan antara individu dengan budaya tertentu. Batik sebagai sarana dalam penanaman nilai-nilai budaya dan pembentukan karakter anak, sangatlah penting untuk dikenalkan pada anak sedini mungkin sebagai proses pembentukan karakter anak untuk memperkokoh karakter bangsa (Astuti, 2017).

Berdasarkan hasil wawancara dengan Agus, didapatkan hasil bahwa Agus suka berbusana batik karena terinspirasi dari ayahnya. Ayah Agus adalah seorang Pegawai Negeri Sipil yang sering berbusana batik. Agus memiliki persepsi bahwa individu yang berbusana batik terlihat berwibawa. Batik memberi kesan elegan dan menaikkan harga diri. Agus juga mengatakan bahwa di rumah selalu tersedia baju batik. Ibu dari Agus selalu menjahitkan kemeja batik untuknya.

Tabel 4 menunjukkan bahwa pertimbangan utama mengapa responden mengenakan busana batik adalah motif, model, atau bahan batik. Contoh dari pernyataan menunjukkan pertimbangan utama responden berbusana batik seperti:

"Motif batik dan warna serta model outfitnya"

"Corak dan motifnya bisa dipakai kapan pun dan dimana pun dan tidak pernah lekang oleh zaman"

"Saya suka batik keseringan kainnya adem"

Berdasarkan hasil wawancara peneliti dengan Agus dan Siska didapatkan informasi yang berbeda. Agus menjelaskan pertimbangannya berbusana batik adalah karena menyukai pakaian yang formal. Batik selalu identik dengan kesan formal. Agus merasa lebih dewasa dan lebih dihargai saat berbusana batik. Menurut Siska, pertimbangannya untuk berbusana batik dilihat dari bahan, motif, dan model pakaian. Siska menyukai jenis kain batik yang nyaman, terutama jenis kain pada batik tulis. Kemudian Siska melihat motif batik tersebut. Siska tidak dapat menyebutkan nama motif batik tersebut namun responden mengatakan bahwa responden menyukai motif batik berasal dari Banyuwangi yang berwarnawarni. Pertimbangan terakhir adalah model pakaian batik. Siska menyukai model pakaian batik yang modis (fashionable).

Tabel 5 menunjukkan bahwa intensi utama responden dalam berbusana batik adalah motif, model, atau bahan batik. Contoh pernyataan menunjukkan pertimbangan utama responden berbusana batik seperti:

"Saya menyukai motif dan juga bahannya yang beragam sesuai dengan kekhasan (filosofi tertentu) dari daerah asalnya"

"Motif unik"

"Yang penting motif dan modelnya bagus"

Marwati (2011) menuliskan bahwa batik menjadi habitus dari gaya hidup sebagian masyarakat Indonesia. Dengan mengenakan baju batik maka diharapkan akan muncul citra:

a. Mahal, karena batik tulis tergolong mahal dan mewah,

b. Sadar budaya, karena batik merupakan warisan yang harus dilestarikan,

c. Peningkatan status, karena batik dengan motif tertentu dulunya hanya dipakai kalangan raja saja.

Kesimpulan yang dapat dipaparkan berdasarkan penjelasan di atas adalah perilaku berbusana batik pada generasi muda disebabkan oleh alasan estetika, prestise, fashionable, identitas bangsa, dan flexibility. Berdasarkan 
hasil analisis data deskriptif dan juga wawancara dapat disimpulkan bahwa alasan utama perilaku berbusana batik pada generasi muda adalah nilai estetika (motif, corak, nilai seni). Motif batik yang memiliki nilai filosofis saat ini dipandang sebagai nilai seni yang unik. Batik dianggap klasik namun masih relevan dikenakan dalam kehidupan modern.

Perilaku berbusana batik pada generasi muda bila dijelaskan dengan theory of planned of behavior (Ajzen, 2005) disebabkan adanya intensi yang didorong oleh sikap terhadap batik, norma subyektif, dan kontrol pada perilaku berbusana batik. Berdasarkan hasil kuesioner terbuka dan wawancara diketahui bahwa nilai estetika batik menjadi sikap terhadap batik dan kontrol terhadap perilaku yang mendorong niat menggunakan batik generasi muda. Keluarga merupakan norma subyektif generasi muda yang mendorong mereka suka memakai batik.

Berdasarkan pemaparan bagian diskusi dan kesimpulan, saran dari penulis antara lain sebagai berikut:

1. Masyarakat pengguna busana batik perlu memahami makna filosofis dari setiap motif batik yang dikenakan. Perlu adanya wawasan mengenai budaya batik yang dapat diberikan melalui proses pendidikan.

2. Penelitian lanjutan dapat menambahkan jumlah responden pada kuesioner terbuka dan wawancara.

\section{Daftar Pustaka}

Ajzen, I. (2005). Attitudes, personality and behavior. New York: Open University Press.

Arti kata estetika. (n.d.). Diakses dari https://kbbi.web.id/estetika

Astuti, F. (2017). Batik Jlamprang Pekalongan dance as character education Media for early childhood in kindergarten B TK Batik Pencongan, Wiradesa, Pekalongan. BELIA: Early Childhood Education Papers, 6(2), 103-107. Diakses dari https://journal.unnes.ac.id/sju/index.php/b elia/article/download/17298/9738

Azhar, A. R. \& Siswanto, R. A. (2018). Experimentasi perpaduan motif batik dengan desain kasual. eProceeding of Art and Design, 5 (3), 954-969. Diakses dari https://openlibrary.telkomuniversity.ac.id/ pustaka/files/147107/jurnal_eproc/experi mentasi-perpaduan-motif-batik-dengandesain-kasual.pdf

Cheng, J. T., \& Tracy, J. L. (2014). Toward a unified science of hierarchy: Dominance and prestige are two fundamental pathways to human social rank. In J. T. Cheng, J. L. Tracy, \& C. Anderson (Eds.), The psychology of social status (pp. 3-27). New York: Springer.. Diakses dari http://ubc-emotionlab.ca/wpcontent/files_mf/chengtracy2014chapterd ominanceprestige.pdf

Cholachatpinyo, A., Fletcher, B., Padgett, I., \& Crocker, M. (2002). A conceptual model of the fashion process-part 1: The fashion transformation process model. Journal of Fashion Marketing and Management: An International Journal, 6(1), 11-23. https://doi.org/10.1108/136120202104224 28

Creswell, J. W., Hanson, W. E., Clark Plano, V. L., \& Morales, A. (2007). Qualitative research designs: Selection and implementation. The Counseling Psychologist, 35(2), 236-264. https://doi.org/10.1177\%2F00110000062 87390

Djulius, H. (2017). How to transform creative ideas into creative products: Learning from the success of batik fractal. International Journal of Business and Globalisation, 19(2), 183-190. https://doi.org/10.1504/IJBG.2017.08592 5

Felaza, E. (2015). Conserving Indonesia's nature and culture through empowerment of indegenous technology in creative industry SMEs. The International Journal 
of Management Science and Information

Technology (IJMSIT), (18), 3-10. Diakses dari

https://www.econstor.eu/bitstream/10419/ 178809/1/IJMSIT_y2015_i18_p003010.pdf

Frey, J. H., \& Fontana, A. (1991). The group interview in social research. The Social Science Journal, 28(2), 175-187. https://doi.org/10.1016/03623319(91)90003-M

Galih, B. (2017, Oktober 02). 2 Oktober 2009, UNESCO akui Batik sebagai warisan dunia dari Indonesia. Nasional.kompas.com. Diakses dari https://nasional.kompas.com/read/2017/1 0/02/08144021/2-oktober-2009-unescoakui-batik-sebagai-warisan-dunia-dariindonesia

Gray, N. H. (2010). Bahasa, batik, and bargaining: An exploratory study of the negotiation styles and behaviors of Indonesian managers. Journal of Transnational Management, 15(3), 215228.

https://doi.org/10.1080/15475778.2010.50 4490

Iriani, A. (2013). Using social network analysis to analyze collaboration in Batik Smes. Journal of Knowledge Management, Economics and Information Technology, 3(6), 1-6. Diakses dari http://citeseerx.ist.psu.edu/viewdoc/dow nload?doi=10.1.1.678.3689\&rep=rep $1 \&$ type $=$ pdf

Iskandar \& Kustiyah, E. (2017). Batik sebagai identitas kultural bangsa Indonesia di era globalisasi. GEMA, 52, 2456-2472. Diakses dari https://media.neliti.com/media/publicati ons/62476-ID-batik-sebagai-identitaskultural-bangsa.pdf

Kallio, H., Pietilä, A. M., Johnson, M., \& Kangasniemi, M. (2016). Systematic methodological review: Developing a framework for a qualitative semi-structured interview guide. Journal of Advanced Nursing, 72(12), 2954-2965. https://doi.org/10.1111/jan.13031

Kamis dan Jumat wajib pakai Batik. (2012, April 03). Poskotanews.com. Diakses dari https://poskotanews.com/2012/04/03/kam is-dan-jumat-wajib-pakai-batik/

Kusumodewi, G. \& Sudarwanto, T. (2016). Pengaruh gaya hidup, kualitas produk, dan harga terhadap keputusan pembelian kain batik Mirota Surabaya. Jurnal Pendidikan Tata Niaga, 3 (3), 1-13. Diakses dari https://jurnalmahasiswa.unesa.ac.id/index. php/jptn/article/view/16323/14828

Li, Y., Hu, C. J., \& Yao, X. (2009). Innovative batik design with an interactive evolutionary art system. Journal of Computer Science and Technology, 24(6), $1035 . \quad$ DOI: https://doi.org/10.1007/s11390-0099293-5

Maner, J. K., \& Case, C. R. (2016). Dominance and prestige: Dual strategies for navigating social hierarchies. Advances in Experimental Social Psychology, 54, 129-180. DOI: 10.1016/bs.aesp.2016.02.001

Marwati, S. (2011). Batik sebagai gaya hidup masyarakat Yogyakarta dan Surakarta. Ornamen Jurnal Kriya Seni ISI Surakarta, 8 (1), 1 - 11. Diakses dari http://jurnal.isi-

ska.ac.id/index.php/ornamen/article/down load/1013/1005

Moersid, A. F. (2013). Re-invensi batik dan identitas indonesia dalam arena pasar global. Jurnal Ilmiah WIDYA, 1(1), 121128. Diakses dari http://ejournal.jurwidyakop3.com/index.php/jurn al-ilmiah/article/view/120/106

Robinson, O. C. (2014). Sampling in interview-based qualitative research: A theoretical and practical guide. Qualitative Research in 
Psychology, 11(1),

$25-41$

https://doi.org/10.1080/14780887.2013.80 1543

Risnamasari, Mujiasih, E. \& Putra, N. A. (2013). Hubungan antara persepsi terhadap kualitas produk dengan intensi membeli batik Qonita pada ibu ibu pengurus Bhayangkari Semarang. Jurnal Empati, 2 (4), 1-9. Diakses dari https://ejournal3.undip.ac.id/index.php/e mpati/article/view/7426/7186

Shokiyah, N. N. (2012). Batik sebagai sarana penanaman nilai-nilai budaya dan pembentukan karakter bangsa. Jurnal Brikolase, 4 (1), 27-38 https://doi.org/10.33153/bri.v4i1.343

Simatupang, T., Afrillia, D., Maharrani, A., Pujiono, J.S. (2016, Oktober 02). Batik mendapat tempat di hati para milenial. Beritatagar.id. Diakses dari https://beritagar.id/artikel/laporankhas/perjalanan-batik-dari-titik-malamhingga

Smit, B. (2002). Atlas. ti for qualitative data analysis. Perspectives in Education, 20(3), 65-75. Diakses dari https://repository.up.ac.za/bitstream/han dle/2263/4813/Smit_Atlas(2002).pdf

Stephenson, N. (1993). The past, present, and future of Javanese Batik: A bibliographic essay. Art Documentation: Journal of the Art Libraries Society of North America, 12(3), 107-113.

Teddlie, C., \& Yu, F. (2007). Mixed methods sampling: A typology with examples. Journal of Mixed Methods Research, 1(1), 77-100. https://doi.org/10.1177\%2F1558689806 292430

Turner III, D. W. (2010). Qualitative interview design: A practical guide for novice investigators. The Qualitative Report, 15(3), 754-760. Diakses dari http://nsuworks.nova.edu/cgi/viewcontent .cgi? article $=1178 \&$ context $=$ tqr $/$
Yunus, U., \& Tulasi, D. (2012). Batik Semiotics as a media of communication in Java. Cultura, 9(2), 143-150. https://doi.org/10.5840/cultura20129210

\section{.}

